Discussion Papers in Economics

\title{
The Impact of School Meals on School Participation: Evidence from Rural India
}

\author{
Farzana Afridi
}

February 2010

Discussion Paper 10-02

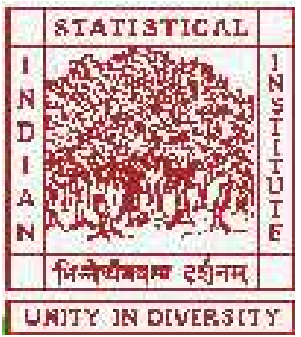

Indian Statistical Institute, Delhi

Planning Unit

7, S. J. S. Sansanwal Marg, New Delhi 110016, India 


\title{
THE IMPACT OF SCHOOL MEALS ON SCHOOL PARTICIPATION: EVIDENCE FROM RURAL INDIA*
}

\author{
Farzana Afridi \\ Planning Unit \\ Indian Statistical Institute \\ 7, S. J. S. Sansanwal Marg, New Delhi - 110016 \\ Phone: +91-11-4149 3942 \\ Email: f.afridi@gmail.com
}

*This paper has benefited from the comments of Tahir Andrabi, Julie Cullen, Jean Dréze, Paul Glewwe, David Lam, Albert Park, Rohini Somanathan, two anonymous referees and seminar participants at the University of Michigan, Syracuse University and the Delhi School of Economics. Special thanks to the district administration of Chindwara, particularly Malay Srivastava, for its cooperation in the conduct of the study. Financial support for this research was provided by the Population Council and the Marshall Weinberg International Research Fellowship from the Population Studies Center at the University of Michigan. All errors are my own. 


\begin{abstract}
$\underline{\text { Abstract }}$
This paper assesses the effect of transition from monthly distribution of free food grains to the daily provision of free cooked meals to school children on enrollments and attendance in a rural area of India. School panel data allow a difference-in-differences estimation strategy to address possible endogeneity of program placement. The results suggest that program transition had a significant impact on improving the daily participation rates of children in lower grades. The average monthly attendance rate of girls in grade 1 was more than 12 percentage points higher while there was a positive but insignificant effect on grade 1 boys' attendance rate. The impact on enrollment levels was insignificant.
\end{abstract}

JEL Classification: I21, I28, I38

Key Words: school meals, attendance, enrollment 


\section{Introduction}

This study evaluates the impact of a nationally mandated program of providing free school meals on improving participation rates of primary school age children in a rural area of India. Universalization of primary schooling by 2015 is one of the eight Millennium Development Goals adopted at the United Nations (UN) Summit in 2000. Assessment of the progress made since shows that South Asia, besides sub-Saharan Africa, is lagging behind in attaining this objective (Glewwe and Zhao, 2006). With almost $70 \%$ of the primary school age population in the region coming from India, the country's poor performance has been a primary driver of the slow progress made since the UN declaration (Glewwe and Zhao, 2006). Ironically, the elementary education system of India is one of the largest in the world. ${ }^{1}$ But despite its seemingly extensive coverage almost 40 million children do not reach grade 5 (Government of India, Department of Education, 2003). Dropout rates are high and primary school completion in 1998-99 was a mere 58.2\% (National Family Health Survey (NFHS), 1998-99).

As in most developing countries, one of the key reasons cited for low levels of school participation in India is the cost, including the opportunity cost, of education (NFHS, 1998-99). Although tuition in public primary schools is negligible and almost completely subsidized, the overhead costs of books and uniforms can be quite high, dissuading poor families from sending their children to school (Public Report on Basic Education for India (PROBE) Team, 1999). ${ }^{2}$ Not surprisingly, therefore, both survey and experimental studies suggest that programs, which reduce the cost of schooling, can be effective means of improving participation rates in developing countries (conditional cash transfer programs: Schultz (2004) and Morley and Coady (2003); free uniforms and textbooks: Kremer et al. (2002); raw food grains program: Ravallion and Wodon (2000)). However, enrollment is a noisy measure of participation, 
especially in developing countries. Daily school participation may be lower than suggested by enrollment levels. Although data on daily attendance is virtually absent in India, some evidence suggests that there is significant student absenteeism. ${ }^{3}$ Low attendance rates can be attributed to poor quality of schooling as well as to household financial constraints. ${ }^{4}$ Improvements in daily attendance could, arguably, raise academic performance and thereby reduce dropout rates and improve primary school completion rates. In recent years, therefore, there has been growing emphasis on providing free school meals as a targeted in-kind transfer.

Given the anticipated benefits of such a scheme, the National Program of Nutritional Support to Primary Education (or the Mid-day Meal Scheme) was launched in India in 1995. The scheme entitles each enrolled child to a meal, which does not vary in quantity or content across grades and gender, on the school premises each school day. The program currently benefits 120 million primary school children across the country making it one of the largest school feeding programs in the world..$^{5}$

This paper studies the impact of transition of the scheme from a take-home program (monthly provision of free, raw foodgrains) to its current form of providing free cooked meals on school participation in a rural area of India. It attempts to provide new policy insights in two ways. First, despite the growing emphasis on provision of cooked school meals, the evidence on its impact on participation in India (and of similar programs in other developing countries), particularly in comparison to a relatively less expensive take-home program, is startlingly meager. ${ }^{6}$ In a rare survey study of the effect of school quality on participation in rural India, Dreze and Kingdon (2000) find that provision of mid-day school meals increased enrollment of girls but not of boys in primary schools. However, their result has to be interpreted cautiously since the authors did not address the issue of endogeneity of program placement. A few studies 
for other developing countries also indicate a positive participation impact (Vermeersch and Kremer, 2005; Ahmed, 2004) of school meals. Second, while enrollment has been the focus of most research on this scheme, school meal programs are also directed at the poor daily attendance of students. ${ }^{7}$ In a scenario where enrollment does not necessarily imply daily presence in school, enrollment outcomes might not provide a complete picture of the effect of providing free meals on participation rates.

The study utilizes school panel data collected in a rural area of India. It adopts a difference-in-differences estimation strategy, comparing the difference in participation before and after the introduction of the program in schools that transitioned from providing free food grains to serving cooked meals within the first six months of a new academic year to that of a control group whose program participation status did not change during this period. This allows us to control for time invariant unobservables that are correlated with program placement and participation.

To provide a brief overview of the results - there was a significant effect of the introduction of cooked school meals on daily school participation, particularly of girls and of children in lower grades. The average monthly attendance rate of grade 1 girls was more than 12 percentage points higher due to program transition. There is a positive but insignificant impact of the scheme on the attendance rate of boys in grade 1 . The impact on attendance of girls and boys in high grades is insignificant. The results also suggest that the on-site school meal program had an insignificant effect on enrollment levels.

The paper begins with a brief discussion of the expected response of beneficiary households to the transition in the nature of the school meal program. The institutional characteristics of the meal program in the survey region are described in section 3 . Section 4 
provides details on the data and methodology used in estimating the impact of program transition. The results are presented in section 5. Section 6 discusses the results and concludes.

\section{Response of households to school meals}

Distribution of free food grains and the provision of cooked meals in schools may impact the incentives of potential beneficiaries differently. The distribution of free food grains in the survey areas was once a month and was, in practice, conditional on student enrollment. The uptake of the cooked meals program is conditional on enrollment and daily attendance since meals are served on-site. The net impact of this change in program characteristic (assuming that the value of the transfer per month per child is the same in both programs and school quality remains unchanged) on individuals' school participation depends on the behavioural response of households to this transition.

The raw foodgrains program allowed for sharing of the transfer among family members but the on-site cooked meals program is targeted at the child potentially reducing leakage of benefits to other household members. If households reallocate food at home in response to the provision of on-site school meals there could be comparable effects of the two types of programs on children's school enrollment. A second reason for non-effect of program transition could be that the opportunity costs of sending a child to school may be substantive for families that need to choose between schooling and engagement in productive labour. This choice could be more stark for older children. In such a case the on-site program may not provide any additional incentives for enrollments. Daily participation could also be unaffected if the opportunity costs of regular presence in school is higher than the implicit program subsidy.

Alternately, there could be two reasons for a positive participation effect. First, if the scheme creates a 'labeling' effect (Kooreman, 2000) and there is no reallocation of household 
resources away from the program beneficiary, cooked meals may provide greater enrollment and daily participation incentive if parents perceive the program as improving the health and learning outcomes of the targeted child. Second, if the transition from take-home to on-site program results in the child (as against other household members) receiving most of the transfer (Afridi, 2009), the attraction of a meal in school could, through child agency, make it easier for parents to induce the child to attend school more regularly. Similarly lower opportunity costs of school attendance due to daily meal provision could increase parental incentives for ensuring the child's presence in school (Ravallion and Wodon, 2000).

To sum, participation may be unchanged or increase due to program transition. Since some of these conflicting responses could be simultaneous, the net impact of the transition on enrollments and daily attendance is an empirical question.

\section{$3 \quad$ Background}

\section{A. The school feeding program in India}

The National Program of Nutritional Support to Primary Education was initiated by the federal government of India in August 1995 (Government of India, 1995). The program mandated provision of free meals in all public primary schools (not in private primary schools) across the country. Every child enrolled in grades 1 to 5 was to be served wheat porridge (sweet and salty, on alternate days) cooked from 100 grams of raw wheat or rice on the school premises during the school lunch break (or mid-day and hence also called the mid day meal (MDM) program), providing $413.80 \mathrm{kcal}$ and 8.20 grams of protein. The state governments were responsible for financing the cost of converting food grains, provided free by the federal government, into cooked meals. States that could not raise resources were allowed, in the interim, to distribute free grain rations to each enrolled child at the rate of 3 kilograms per school month conditional on a 
minimum monthly attendance of $80 \%$ per student. However, this conditionality was not strictly imposed. A Supreme Court of India judgment in 2001 directed all state governments, which were yet to implement the program, to provide cooked meals in all targeted schools within six months.

\section{B. The school feeding program in the survey region}

This paper draws upon survey data collected in one of the eleven census blocks of Chindwara district in Madhya Pradesh (MP) in 2004. ${ }^{8}$ MP is one of the most underdeveloped states in the country, in terms of both poverty ratios and educational attainment. According to the National Sample Survey (NSS), 11\% of all children between 6 to 11 years who were not in school in 1999-2000 in India were in Madhya Pradesh. During the same period rural poverty in MP was $30 \%$ (Deaton and Dreze, 2002), 4 percentage points higher than the average rural poverty in the country. The potential impact of a school subsidy program in this region can, therefore, be substantial.

Chindwara, located in south central MP, is one of the largest in the state with a population of almost 2 million in 2001. The surveyed block is one of the officially designated 120 economically deprived census blocks in the state. In this block public primary schools were distributing grain rations to all enrolled students up until April 2003, despite the court verdict mandating cooked school meals in 2001. Although most public schools here transitioned from distributing food grains to providing meals in school in July 2003 (the first month of a new academic year), some continued to distribute wheat grains at the rate of 2 kilograms per student per school month even after July. This quantity of food grains was equivalent to the 100 grams of wheat provided under the cooked meal program on a school day (i.e. a school year comprises of 10 school months each containing 20 school days on average). 
The administrative and financial responsibility of implementing the meal program in all public primary schools in a village in MP lay with the elected village governing body or GP (Gram Panchayat). ${ }^{9}$ Under the guidelines of the state government of MP, GPs were expected to use funds obtained through devolution of revenue collected by state governments to finance the school meal program. Thus, the implementation of the school meal scheme may have been endogenous to that particular village or community due to the institutional characteristics of the program.

\section{$4 \quad$ Empirical analysis}

\section{A. Data}

41 of the 150 villages in the census block were randomly selected for a school survey. Within each village all public and private primary schools were surveyed during an unannounced visit in January and February 2004 for information on the school meal program, student participation and school infrastructure. In total, information was obtained for 74 primary school, including 10 private schools in the selected census block. For the purpose of the analysis the sample is restricted to the public primary schools only. ${ }^{10}$

Within each school aggregate participation data on enrollment and attendance was obtained at the grade and gender level from official school registers for two school months, July and December 2003. The enrollment level was obtained by counting the total number of students listed in the school register in a grade by gender in that month. The average monthly attendance rate was calculated by first computing the average number of attendees on a school day in that month (by grade and gender) or the average monthly attendance level. This was obtained by summing the total number of attendees on each school day in that month and dividing it by the 
total number of days school was held in that month. The average monthly attendance rate then is the average attendance level over the enrollment level in that month (in percentage terms).

Besides the participation data, information was gathered on the timing of the transition from monthly distribution of raw food grains to daily provision of cooked meals on school premises. Of the 64 public primary schools, 41 schools implemented the cooked school meal program after July and before December, 2003 (22 implemented the program in August, 7 in September, 9 in October and 3 in November 2003). These schools were distributing raw food grains in July and transitioned to serving cooked meals before December. The remaining 23 schools did not change their implementation status during this period. This group includes 17 schools which implemented the cooked meal program in July and continued providing cooked meals through December. 6 schools did not have a cooked school meal program in either July or December. Of these, 3 schools were not serving cooked meals in either month but were distributing foodgrains and 3 schools were not even distributing foodgrains. Details on the number of teachers and physical infrastructure, such as functional toilet and drinking water facility, were also obtained for each school in January and February 2004.

\section{B. Estimation strategy}

The ideal estimation strategy for evaluating the impact of the cooked meal scheme on school participation would be randomization of program participation at the individual level. But since the scheme was mandated for all public primary schools, randomization of program participation at the individual or even school level was not possible. However not all public primary schools in the survey region had implemented the program at the same time. The staggered implementation of the school meal program from the beginning of the academic year in July 2003 makes possible a before and after comparison of school enrollment and attendance between 
schools which transitioned from providing raw food grains to cooked meals earlier to those that transitioned later in the first 6 months of the academic year. This difference-in-differences strategy is able to account for possible endogenous program placement by eliminating any time invariant unobservable characteristics that might be systematically related to implementation of the school meal program and school participation. ${ }^{11}$

The 39 treatment schools which were late switchers to cooked meals program (participation in the meal program changed between July and December) comprise the treatment group. The 17 schools which were early switchers to cooked meals program, since they began providing cooked school meals in July itself and continued with the program, comprise the control group. Given that the trends in the 6 schools without the cooked meal program in both months are likely to be very different from the other schools, these schools were excluded from the study. Since all schools implementing cooked meals in December provided food grains in July (treatment) or cooked meals in July (control), the outlined empirical strategy allows comparison of early switchers to late switchers to identify impact of program transition. ${ }^{12}$

The estimating equation is given by,

$$
A_{g c s t}=\alpha_{0}+\alpha_{1} D_{s}+\alpha_{2} D_{t}+\alpha_{3} D_{s} * D_{t}+\alpha_{4} \mathbf{X}_{s} * D_{t}+v_{g c s t}
$$

$A_{g c s t}$ is the aggregate participation rate of gender $g$ in grade $c$ in school $s$ in month $t . D_{s}$ is a dummy variable for a treatment school. $D_{t}$ is a dummy variable for the month - 0 for July and 1 for December. $\mathbf{X}_{\mathrm{s}}$ is a vector of aggregate school level characteristics that may impact participation - pupil-teacher ratio at baseline (July), blackboards per grade, drinking water on premises, functional toilet for girls and overall school enrollment level and attendance rate in July. For instance, if initial pupil teacher ratios are much worse in the control group schools they would have greater drop-out rates relative to the treatment schools and lead to the incorrect 
conclusion that program transition reduced drop-outs. But since these school characteristics do not vary between July and December, 2003 they would drop out of the difference-in-difference analysis. Therefore, each school characteristic is interacted with $D_{t}$ to control for the possibility that they influence program participation. $\quad v_{g c s t}$ is a time varying error term. The coefficient on $D_{s} * D_{t}$, then, is the difference-in-differences estimate of the impact of providing cooked school meals on the average participation rate.

\section{Validity of estimation strategy}

There are three concerns regarding the validity of the outlined empirical strategy. First, the source of variation in the implementation of the cooked school meal program may not be independent of time trends in participation. Although there is no rigorous evidence available on any systematic reason for the staggered program implementation, some evidence suggests that disadvantaged regions or villages may have implemented the program earlier - (1) the Supreme Court of India order of 2001 directs that the school meal program should be implemented in the order of poverty in districts in a state ${ }^{13}$; (2) findings of the PROBE survey (1999) also suggest that school meals were more likely to be targeted at disadvantaged areas. A regression of provision of school meal on village characteristics yields a negative coefficient for the village development index and a positive coefficient for distance from the nearest road by Dreze and Kingdon (2000). (3) A regression of month of implementation of school meal on the sample of schools' village level characteristics using the survey data reveals that villages with less irrigation facility, farther from the nearest city (census block headquarter) and with a scheduled tribe (socio-economically disadvantaged community) GP president were more likely to implement the program earlier. ${ }^{14}$ However, none of these coefficients are statistically significant. Since schools in disadvantaged areas with typically low participation rates were more likely to 
fall in the control group and were more likely to see improvements in participation posttransition, the strategy adopted here would lead to downward biased estimates of impact of the transition to cooked meals program. Thus even if the timing of the program's transition can be linked systematically to participation trends, it would go against finding a program impact.

A second concern is regarding comparability of the control and treatment groups. Table 1 describes the control and treatment groups of schools in detail. A comparison of observable school characteristics of the two groups shows no statistically significant difference between any of the observable characteristics for which data are available in column 3 of Table 1 . As a further test of comparability of the two groups of schools, Figures 1-4 show the average monthly school attendance rates for the same sample of schools in July and December of 2003-04. Figures 1-2 depict the attendance rates for boys in grades 1 to 5 while Figures 3-4 are for girls. Across the two months and groups, the attendance rate in grade one is lower than the upper grades. The attendance rates tend to rise from grade one to two and then decline, particularly for girls in July. Typically, first and fifth grade attendance rate jumps up for both boys and girls, more strongly for the latter, in December compared to July. Though the trends in attendance differ between July and December, they are similar across the two groups of schools and thus comparable across the treatment and control public primary schools. Unfortunately, pre-treatment data, which would provide more reliable comparison of time trends in participation in the two school groups, are not available.

Finally, in developing countries public school records of enrollment and attendance are often suspected of being inflated. What is not clear, however, is whether this exaggeration is at the school level or at a higher level of aggregation. In order to check the validity of the school records the surveyors in this study were asked to match their own count of students with the 
attendance recorded for the day of their unannounced visit. ${ }^{15}$ The correlation between surveyors' own count and the attendance record is 0.98 . This suggests that the official school records were mostly reliable. Furthermore, a difference-in-differences strategy will be able to correct for any bias in the records if there is no change in the degree of incentive to inflate participation figures before and after the introduction of the meal program in the treatment schools. There are two very compelling reasons to believe that this assumption holds. First, food grains were being released to the schools at the beginning of a month based on the enrollment figures, and not the average attendance, in the previous month in the survey region. Second, almost all public schools were distributing raw food grains before the introduction of the cooked meal program. All schools were directed to implement the program from July onwards and, therefore, the quantity of grains released at the rate of 2 kilograms per child per month was the same irrespective of whether the school was implementing the cooked meal program or distributing raw food grains. Thus there should be no differential incentive between treatment and control schools to exaggerate the enrollment records either. Since the nature of the program is unlikely to be correlated with the either the level or direction of the fudging of school records, $\alpha_{3}$ should give a true estimate of program impact. However, if the degree of inflation is so large that it leaves little scope for a possible increase after program implementation, the impact of the school meal program on school participation would be biased downwards.

\section{$5 \quad$ Results}

\section{A. Impact of school meals on daily attendance}

We begin with assessing the impact of program transition on school attendance as an indicator of participation in Table 2. Each column shows separate regressions of the total, boys' and girls' average monthly attendance rate on schools' participation in the cooked meal program. The first 
row reports the coefficient for the difference-in-differences (DID) estimate of impact of the transition. There is a positive but insignificant effect of implementation of the cooked meals program on attendance rates overall and by gender as indicated by the coefficients on the DID term in row one of Table 2. The point estimate of the DID effect for girls is larger in magnitude than for boys. In schools, which transitioned late, the attendance rates were insignificantly lower, as suggested by the negative coefficients on 'participation in cooked meal program after July' for all groups. However, the significantly negative point estimates for December along with the DID estimates may indicate that lower attendance rates in December, relative to July, could be stemmed by the introduction of the cooked school meal program. The positive coefficient on the interaction of December dummy with attendance rate in July suggests that schools with higher initial attendance were likely to see a smaller decline in daily participation in December. There is insignificant impact of other school characteristics on attendance rates.

The program's impact on aggregate attendance rate could be masking variation in its effect across grades and gender. The first five columns in Table 3, therefore, show the results for the average monthly attendance rate of boys in grades 1 to 5 while the next five show the effect on attendance rate of girls. The coefficient on the DID estimate is insignificant across all grades for boys. The point estimate for grade 1 boys is positive but imprecisely estimated. The attendance rate of girls in grade 1 in treatment schools is higher by 12.4 percentage points due to the implementation of the cooked meal program after July as indicated by the DID coefficient in row one. The DID coefficient is insignificant for girls in all other grades. Schools whose program participation status changed after July had lower attendance rates of grade 1 boys and girls as indicated by the negative coefficient in the second row. Again, the negative coefficients on December suggest that there is a time trend in attendance rates across the sample of schools. 
While the constants across grades may indicate that attendance rates are lowest in grade 1 for both genders, the negative coefficient on December shows that the attendance rates of students (more so in the lower grades) decline as the school year progresses. This finding coupled with the DID coefficient (in row one) suggests that the presence of cooked school meals may improve attendance in lower grades. The impact of other school characteristics is insignificant for boys. For girls, the coefficient on the interaction of December with pupil-teacher ratio is negative only for grade 3 and significant only at the $10 \%$ level. The coefficient on the interaction term with functional toilet for girls is positive for all grades and significant for grades 2, 3 and 4 . This, coupled with the December coefficient, suggests that attendance rates of girls in December in schools with a functional toilet were likely to be greater than in schools without this facility.

\section{B. Impact of school meals on enrollment}

Table 4 shows the results of the analysis of the effect of introducing cooked meals on school enrollment levels. The point estimate of the DID effect for all children is insignificant suggesting that implementation of the new program did not lead to higher enrollments. The coefficient on December indicates that students drop out as the school year progresses, particularly girls. Schools with higher enrollments in July were likely to see lower drop-outs in December as suggested by the coefficient on December*school enrollment in July in all the columns. The coefficients on the month of interaction with average school characteristics are insignificant throughout.

A further disaggregation of the data by grade and gender and in Table 5 shows similar results. The coefficient on the DID term is insignificant across gender and grades as reported in row one of the first column. The December coefficients do not suggest any systematic trend for boys but do suggest a strong time trend in enrollment levels which varies across grades for girls. 
Enrollment levels of girls fall in December, the decline being larger in upper grades as suggested by the significantly negative coefficient on December in grades 2 to 5 . This may suggest that girls in higher grades are more likely to drop out of school than boys in the same grades as the school year progresses. Indeed, while the level of enrollment may fall in higher grades in December relative to July, the trend in the attendance rate is opposite as suggested by the coefficient on December for girls in upper grades (see Table 3). Large negative coefficients on the December dummy along with the insignificant coefficient on the DID estimates, however, raise a concern that despite the introduction of cooked meals participation, enrollments in particular, may be declining during the school year. It is difficult to interpret the coefficients on the interacted school characteristics as they are mostly insignificant and do not suggest any systematic relationship with participation of boys and girls. The coefficients on the pupil-teacher ratio interaction, however, is significantly positive for boys in grades 1 and 2 , suggesting that drop-outs in December may be lower in schools that have larger classes at baseline. But this coefficient is significantly negative for grade 4 and 5 girls, suggesting the opposite.

\section{Robustness checks}

In this section we discuss sensitivity analyses of the above results. First, schools in the survey region accepted new students only until the end of September. Although parents may enroll their child in school even if the school does not provide cooked meals by September in expectations of the program being implemented later in the academic year, significant enrollment effects may occur if the school begins to serve cooked meals before October. Therefore, as a robustness check for enrollment effects, treatment was redefined narrowly as implementation of program by September. ${ }^{16}$ The impact of the transition to cooked meals on enrollment levels remained insignificant. Second, in order for the attendance rate measure to account for any changes in the 
enrollment level due to the meal program and possibly biasing the program's impact on attendance rates we also ran the analysis for the average level of attendance. The results were similar to that for attendance rates but were not significant. The coefficients on DID term indicated that there may be an increase in the number of girls attending grade 1 by about 1 and grade 1 boys by 0.5 student per school day. To conserve space, the full results are not presented in the paper but are available upon request.

\section{Caveats}

The analyses indicate that the cooked meals program significantly improved the attendance rates, particularly of girls, but not enrollment levels. The latter result does not necessarily imply that school meal programs are not substantially effective in increasing enrollments. Since schools were distributing raw food grains in the survey region before transitioning to serving cooked meals, the results might suggest that the subsidy provided by the latter scheme did not dramatically affect enrollment incentives over and above those provided by the raw food grains program. This is more apparent from the fact that the difference between the cash value of the two programs is marginal (equivalent to the value of ingredients other than food grains used in cooked meals) since more than $76 \%$ of the cooked meal subsidy consisted of the value of food grains. Given that availing the subsidy provided by the cooked meals requires daily school attendance, one would expect the program's impact to be more significant on this indicator of participation than on enrollments.

While interpreting these results and drawing policy conclusions a few caveats, however, must be kept in mind. First, the point estimates may be imprecisely estimated due to the small sample size and/or the downward bias introduced by the estimation strategy as discussed in section 4. Using the data from the sample, power calculations show that the sample size in this 
study will be able to detect a true difference of means of 5.5 percentage points in the attendance rate and 33.5 children in enrollment levels between the control and treatment groups at $5 \%$ significance level with $80 \%$ power. Thus, if the true difference-in-differences in the aggregate participation rates between the control and treatment groups is small (particularly for enrollments) it will require a larger sample for detection. Second, the regularity of school meal provision improved over the academic year in control schools but the small sample size does not allow for analysis by program regularity. The estimates of program impact presented here may be biased downwards due to the provision of meals more regularly in months after July in the control schools (i.e. those which were providing meals in July and December). Third, since parents may have expectations about the program being implemented later in the academic year the enrollment figures in July could themselves be high again biasing the program effects in the analysis here downwards.

\section{Conclusions}

In this paper we used school panel data from a rural area of India to investigate whether transition in a nationally mandated school meal program from provision of raw food grains to cooked meals has been successful in improving school participation rates.

The results indicate that transition to the cooked school meal program may not have improved the enrollment levels over and above the effect which may have been induced by the pre-existing program of distributing raw food grains to primary school students. However, the transition to provision of cooked meals did lead to an increase in the attendance rate, particularly of girls in lower grades. The attendance rate of girls in grade 1 is 12.4 percentage points higher in treatment schools. The magnitude of the treatment impact is positive but insignificant for first 
grade boys. The program's impact on daily attendance decision, thus, may have been greater than that for enrollments.

The results imply that the cooked meal scheme program may be effective in raising the daily school participation of children in lower grades compared to the off-site dry rations program. The survey evidence suggests that schools in the survey area were not following the official guideline of conditioning distribution of food grains on monthly attendance of each student but were instead conditioning on enrollment. The cooked meals program, on the other hand, is conditional on enrollment and daily attendance since meals were served on-site. Thus, we see no impact on enrollments probably because the new program did not provide any additional incentives.

There could be two possible reasons for grade or age effects of daily participation. First, since the food transfer was grade or age invariant it effectively gave a proportionately larger subsidy to lower grades. The cash value of the cooked school meals (food grains and other ingredients including oil, sugar and salt) was equivalent to more than $160 \%$ of the annual cost of public schooling borne by households in the survey area for a child in grade 1 and $78 \%$ of the costs for grade 5 as shown in Table 6 . Analysis of 24-hour individual food consumption recall data collected from children in the same survey area suggests that the total daily calorie intake was larger for older children. Thus, the school meal also formed a larger proportion of the total daily food intake of younger children. This could be particularly true for girls who are more likely to be provided fewer daily nutrients within the household in India (Pitt, Rosenzweig and Hassan, 1990). A second, and related reason, for the differential age effect could be that the opportunity cost of sending children to school may be higher for older children who are more 
likely to be engaged in productive labour. Thus the school meal subsidy may significantly affect the schooling decisions of those with relatively lower opportunity costs.

In conclusion, the new scheme affected the attendance decisions of those whose school participation rate was on the margin: those whose attendance rates were low in the absence of the program and for whom the food transfer significantly lowered the opportunity cost of schooling. These results are supported by the evidence from previous survey data and anecdotal evidence on the impact of the meal program in India (Dreze and Goyal, 2003; Dreze and Kingdon, 2000). These studies suggest that school meal programs are particularly effective in increasing the school enrollment rates of first graders. Qualitative data on perceptions of school headmasters and parents from this survey also suggests that younger children are more attracted to attending school due to the program which makes it easier to ensure that their school participation is more regular.

While the benefits of transitioning to cooked school meals may include improvements in daily participation and nutritional intakes of program participants (Afridi, 2009), the implicit (viz. effects on quality of teaching) and explicit cost of this program may be higher than raw food grains distribution. Any policy recommendation, therefore, must involve a cost-benefit analysis of the two types of school meal programs. Although such a detailed cost-benefit analysis is beyond the scope of this paper, there are two broad policy implications of the results in the paper. First, targeted school subsidies can be an important policy instrument for making regular schooling more desirable for children of resource poor households. A policy recommendation, therefore, is to condition school transfers on attendance along with placing mechanisms for monitoring attendance records in schools. Second, it is possible that school subsidies, which even implicitly target girls, can be effective in improving girls' participation in education. 
${ }^{1}$ According to official figures, there are about 150 million enrolled children in nearly 800 thousand schools throughout the country (Government of India, Department of Education, 2003). ${ }^{2}$ The PROBE Team (1999) report estimates that the average annual cost of sending a child to a rural primary school in 1996 was Rs. 318. This is far from negligible, given that between 199096 more than $40 \%$ of the Indian population lived on less than \$1 a day in 1993 PPP terms (United Nations, Statistical Yearbook for Asia and the Pacific, 2007).

${ }^{3}$ A recent survey conducted in 21 states by the Indian Human Resource Development Ministry (Hindustan Times, August 21, 2007) finds that in most north Indian states student attendance averages around $60 \%$ on a school day in public primary schools. Duflo, Hanna and Ryan's (2007) paper on teacher absenteeism in primary schools in Rajasthan also suggests a daily attendance rate of about $60 \%$ for students.

${ }^{4}$ Which of these two factors has a greater effect on school attendance is an empirical question. Duflo, Hanna and Ryan (2007) find no significant effect of increased teacher presence on students' daily attendance in schools in Rajasthan. Conditional cash subsidy provided under Progresa in Mexico lead to a significant effect on enrollment but not attendance (Schultz, 2000). ${ }^{5}$ Human Resource Development Ministry website at http://education.nic.in/mdm/mdmstatus.asp ${ }^{6}$ A few survey studies (Dreze and Goyal, 2003; Government of India, 2000; Laxmaiah et al., 1999) have evaluated the impact of cooked school meals in India by comparing enrollment and attendance rates across academic years within treatment schools or through a cross-sectional comparison of participation rates in treatment and control schools. Although the results mostly show success of the program in raising enrollment and attendance rates, especially of girls, the estimation strategies neither account for the endogeneity of program placement nor the concurrent introduction of other public programs which could impact school participation rates. 
${ }^{7}$ To the best of our knowledge, the only school meal evaluation which studies the impact on daily attendance is for Bangladesh where school attendance increased by 1.3 days per month (Ahmed, 2004) with the provision of meals. Vermeersch and Kremer's (2005) results are for a pre-school feeding program in Kenya.

${ }^{8}$ Districts in India are subdivided into census blocks. In 2001 there were a total of 48 districts and 311 census blocks in MP.

${ }^{9}$ Each GP typically consists of 1 to 5 villages, including all the public primary schools therein, within its purview.

${ }^{10}$ It is unlikely that a significant proportion of the population was switching between schools in response to the implementation of the school meal program. Private primary schools are rare in this region and significantly more expensive. $96.9 \%$ of the sampled households in the survey had enrolled their child in a public primary school within the residing village. Moreover, $97.8 \%$ of all children currently enrolled in a public primary school had resided with the same household for all of the previous 12 months.

11 In agrarian economies children's daily attendance may vary by agricultural seasons since during harvests children are usually employed either on the family farm or for daily wages on someone else's land lowering average attendance in schools. But in both July and December agricultural activity is low in this rural area, thus, we do not expect the average daily attendance of children to be systematically different between the two months.

${ }^{12}$ When the control group includes only those schools not serving cooked meals in both July and December, the effects of program transition are similar to the results discussed in section 5. But since concerns regarding small sample bias, non-comparability of the treatment and control 
group due to different time trends and heterogeneity within the control group are greater with this definition we do not report these results.

${ }^{13}$ Quoting Supreme Court of India order (2001): “... Those governments providing dry rations instead of cooked meals must, within three months, start providing cooked meals in all government and government assisted schools in half the districts of the state (in order of poverty), and must within a further period of three months extend the provision of cooked meals to the remaining parts of the state."

14 The seat of the GP president, in GPs where the majority of the population is socioeconomically disadvantaged (scheduled tribes), is reserved for an individual belonging to a scheduled tribe by the Constitution. Details of this regression analysis are excluded from the paper but are available upon request.

${ }^{15}$ Since the visits were during the school lunch hour the teachers had already taken the roll call for that day.

16 A comparison of the observable characteristics of schools (viz. Table 1) based on the definition of treatment as "transition to cooked school meals after July but before October" does not show any significant differences between control and treatment schools. 


\section{References}

Afridi, Farzana. (2009) Child Welfare Programs and Child Nutrition: Evidence from a Mandated School Meal Program in India. Journal of Development Economics, Forthcoming.

Ahmed, Akhter U. (2004) Impact of Feeding Children in School: Evidence from Bangladesh. International Food Policy Research Institute, Washington, DC.

Deaton, Angus and Jean Dreze (2002) Poverty and Inequality in India. Economic and Political Weekly, September 7, pp. 3729-3748.

Dreze, Jean and Aparajita Goyal (2003) Future of Mid-Day Meals. Economic and Political Weekly, November 1, pp. 4673-4683.

Dreze, Jean and Geeta Gandhi Kingdon (2000) School Participation in Rural India. Review of Development Economics, 5(1), pp. 1-33.

Duflo, Esther, Rema Hanna and Stephen Ryan (2007) Monitoring Works: Getting Teachers to Come to School. Working Paper 103, BREAD.

Glewwe, Paul and Meng Zhao (2006) Attaining Universal Primary Completion by 2015: How much will it Cost? In: J. Cohen, D. Bloom and M. Malin (eds) Educating All Children: A Global Agenda (MIT Press).

Government of India (1995) Nutrition Support to Education. Report of the Committee on Mid Day Meals.

Government of India (2000) A Comparative Study of Nutritional Support to Primary Education in Orissa and Tamil Nadu. Planning Commission, New Delhi.

Government of India (2003) Selected Educational Statistics, 2002-03. Department of Education, Ministry of Human Resource Development. 
Hindustan Times (2007) Most Bihar Kids Bunk School. Hindustan Times, August $21^{\text {st }}$.

Kremer, Michael, Sylvie Moulin and Robert Namunya (2002) Unbalanced Decentralization. Mimeo, Brookings Institution, Washington, DC.

Kooreman, Peter (2000) The Labeling Effect of a Child Benefit System. American Economic Review, 90(3), pp. 571-583.

Laxmaiah, A., K.V. R. Sarma, D. Hanumantha Rao, C. G. Reddy, M. Ravindranath, M.V. Rao and K. Vijayaraghavan (1999) Impact of Mid Day Meal Program on Educational and Nutritional Status of School Children in Karnataka. Indian Pediatrics, 36, pp. 1221-1228.

Morley, Samuel and David Coady (2003) From Social Assistance to Social Development: Targeted Education Subsidies in Developing Countries. Center for Global Development (CGD) and International Food Policy Research Institute (IFPRI).

National Family Health Survey of India (1998-99) National Family Health Survey of India - 2. International Institute for Population Sciences, Mumbai.

Pitt, Mark M., Mark Rosenzweig and Md. Nazmul Hassan (1990) Productivity, Health and Inequality in the Intrahousehold Distribution of Food in Low Income Countries. American Economic Review, 80(5), pp. 1139-1156.

Ravallion and Wodon (2000) Does Child Labor Displace Schooling? Evidence on Behavioral Response to an Enrollment Subsidy. Economic Journal, 110 (462), pp. 158-175.

Schultz, T. P (2000) Impact of PROGRESA on School Attendance Rates in the Sampled Population. International Food Policy Research Institute, Washington, D.C.

Schultz, T.P (2004) School Subsidies for the Poor: Evaluating the Mexican Progresa Poverty Program. Journal of Development Economics, 74(1), pp. 199-250. 
The PROBE Team (1999) Public Report on Basic Education in India. (Oxford University Press:

Delhi)

United Nations (2007) Statistical Yearbook for Asia and the Pacific, Economic and Social Commission for Asia and the Pacific, New York.

Vermeersch, Christel and Michael Kremer (2005) School Meals, Educational Achievement and

School Competition: Evidence from a Randomized Evaluation. Working Paper 3523, World Bank.

Web Reference: http://education.nic.in/mdm/mdmstatus.asp 
Table 1: Public Primary School Characteristics

\begin{tabular}{|c|c|c|c|}
\hline School Characteristics & $\begin{array}{l}\text { Treatment Group of Schools } \\
\qquad \begin{array}{c}(\mathbf{N}=39) \\
(1)\end{array}\end{array}$ & $\begin{array}{c}\text { Control Group of Schools } \\
\qquad \begin{array}{c}(\mathbf{N}=17) \\
(2)\end{array}\end{array}$ & $\begin{array}{l}\text { Difference } \\
(1)-(2)\end{array}$ \\
\hline $\begin{array}{l}\text { Cooked School Meals in July? } \\
\text { Cooked School Meals in December? }\end{array}$ & $\begin{array}{l}\text { No } \\
\text { Yes }\end{array}$ & $\begin{array}{l}\text { Yes } \\
\text { Yes }\end{array}$ & \\
\hline Tuition for five years of primary schooling (Rs.) & $\begin{array}{l}66.79 \\
(7.642)\end{array}$ & $\begin{array}{l}62.32 \\
(9.845)\end{array}$ & $\begin{array}{c}4.46 \\
(13.290)\end{array}$ \\
\hline Pupil-teacher ratio in July & $\begin{array}{l}52.02 \\
(3.993)\end{array}$ & $\begin{array}{l}62.28 \\
(13.508)\end{array}$ & $\begin{array}{l}-10.27 \\
(10.705)\end{array}$ \\
\hline Blackboards per grade & $\begin{array}{l}0.63 \\
(0.045)\end{array}$ & $\begin{array}{c}0.52 \\
(0.049)\end{array}$ & $\begin{array}{l}0.11 \\
(0.076)\end{array}$ \\
\hline Drinking water on school premises & $\begin{array}{l}0.41 \\
(0.080)\end{array}$ & $\begin{array}{l}0.53 \\
(0.125)\end{array}$ & $\begin{array}{l}-0.12 \\
(0.146)\end{array}$ \\
\hline Toilet facility on school premises & $\begin{array}{l}0.10 \\
(0.049)\end{array}$ & $\begin{array}{l}0.06 \\
(0.059)\end{array}$ & $\begin{array}{l}0.04 \\
(0.084)\end{array}$ \\
\hline Separate toilet facility for girls & $\begin{array}{l}0.08 \\
(0.043)\end{array}$ & $\begin{array}{c}0.00 \\
(0.00)\end{array}$ & $\begin{array}{l}0.08 \\
(0.066)\end{array}$ \\
\hline School has library & $\begin{array}{l}0.59 \\
(0.080)\end{array}$ & $\begin{array}{l}0.53 \\
(0.125)\end{array}$ & $\begin{array}{l}0.06 \\
(0.146)\end{array}$ \\
\hline School has playground & $\begin{array}{l}0.23 \\
(0.068)\end{array}$ & $\begin{array}{l}0.18 \\
(0.095)\end{array}$ & $\begin{array}{l}0.05 \\
(0.121)\end{array}$ \\
\hline Total enrollment in July (BOYS) & $\begin{array}{l}53.28 \\
(5.028)\end{array}$ & $\begin{array}{l}49.88 \\
(7.938)\end{array}$ & $\begin{array}{c}3.40 \\
(9.242)\end{array}$ \\
\hline Total enrollment in July (GIRLS) & $\begin{array}{l}51.67 \\
(6.345)\end{array}$ & $\begin{array}{l}44.76 \\
(7.029)\end{array}$ & $\begin{array}{c}6.90 \\
(10.693)\end{array}$ \\
\hline Average student attendance rate in July & $\begin{array}{l}0.77 \\
(0.020)\end{array}$ & $\begin{array}{l}0.81 \\
(0.019)\end{array}$ & $\begin{array}{l}-0.04 \\
(0.033)\end{array}$ \\
\hline $\begin{array}{l}\text { Regularity of cooked meal program in } \\
\text { December }\end{array}$ & $\begin{array}{c}0.93 \\
(0.019)\end{array}$ & $\begin{array}{c}0.96 \\
(0.020)\end{array}$ & $\begin{array}{l}-0.03 \\
(0.031)\end{array}$ \\
\hline
\end{tabular}

Note: The treatment group was distributing free food grains in July. The mean tuition reported is the total tuition cost for progressing from grade 1 to 5 in five years. ${ }^{a}$ The proportion of days in the school month that cooked meals were served.

Standard errors in parentheses.

$*$ Significant at $10 \%$, ** 5\% and $* * * 1 \%$ 
Figure 1

\section{Average Monthly Attendance in Schools Whose}

Participation Status Changed

\section{BOYS}

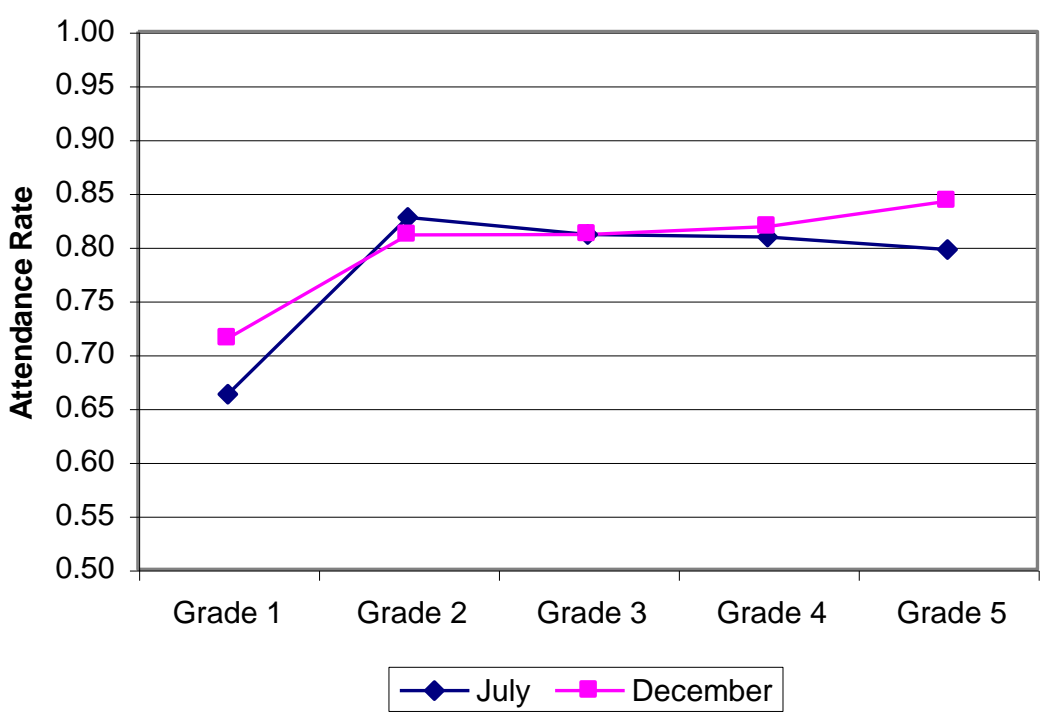

Figure 2

\section{Average Monthly Attendance in Schools Whose} Participation Status Did Not Change

\section{BOYS}

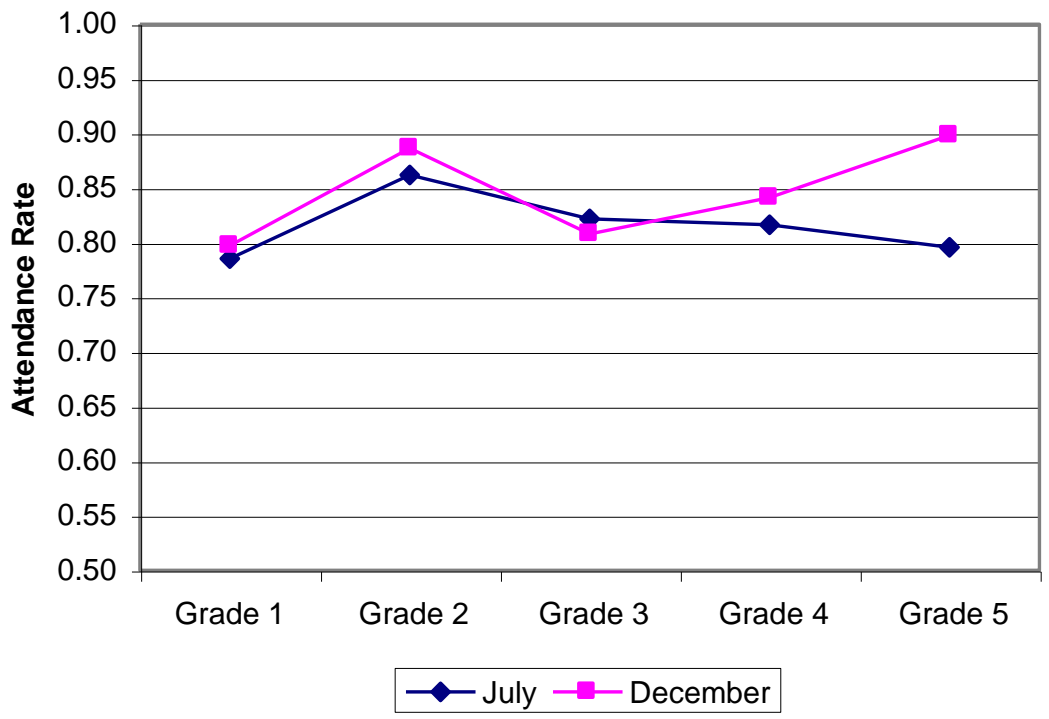


Figure 3

Average Monthly Attendance in Schools Whose

Participation Status Changed

\section{GIRLS}

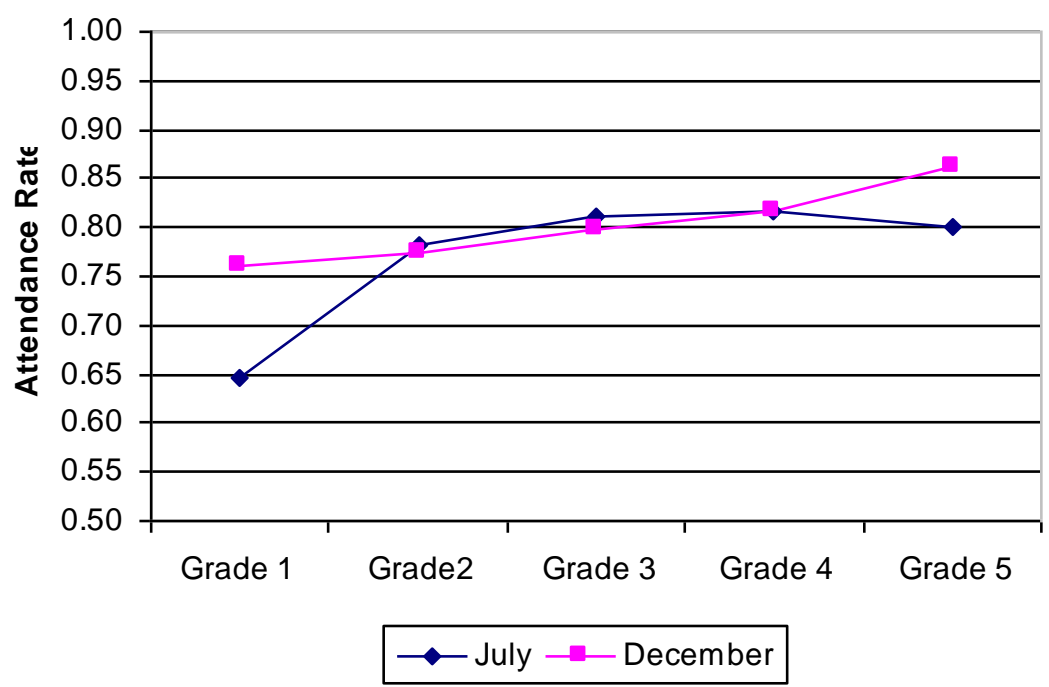

Figure 4

Average Monthly Attendance in Schools Whose Participation Status Did Not Change

GIRLS

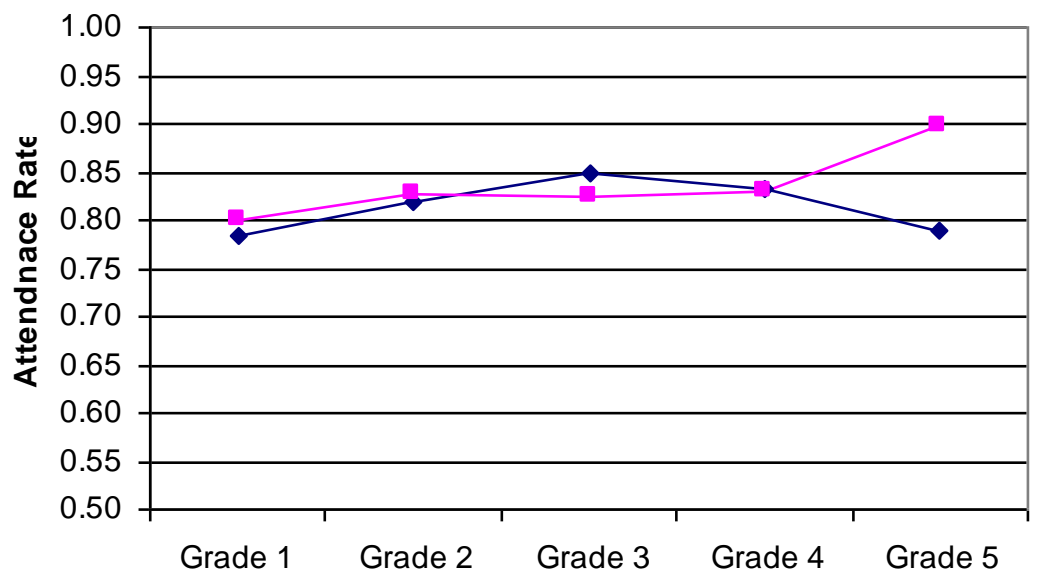

July —- December 
Table 2: Impact of School Meal Program on Monthly Attendance Rates in Public Primary Schools

\begin{tabular}{|c|c|c|c|}
\hline Variables & All & Boys & Girls \\
\hline December*Participation in cooked meal program after July but before December & $\begin{array}{c}0.018 \\
(0.038)\end{array}$ & $\begin{array}{c}0.002 \\
(0.041)\end{array}$ & $\begin{array}{c}0.024 \\
(0.042)\end{array}$ \\
\hline Participation in cooked meal program after July but before December & $\begin{array}{l}-0.045 \\
(0.029)\end{array}$ & $\begin{array}{l}-0.037 \\
(0.032)\end{array}$ & $\begin{array}{l}-0.048 \\
(0.031)\end{array}$ \\
\hline December & $\begin{array}{l}-0.345^{* * * *} \\
(0.070)\end{array}$ & $\begin{array}{l}-0.308 * * * \\
(0.074)\end{array}$ & $\begin{array}{l}-0.381 * * * \\
(0.080)\end{array}$ \\
\hline December*pupil-teacher ratio & $\begin{array}{c}0.000 \\
(0.000)\end{array}$ & $\begin{array}{c}0.000 \\
(0.000)\end{array}$ & $\begin{array}{c}0.000 \\
(0.000)\end{array}$ \\
\hline December*blackboards per grade & $\begin{array}{l}-0.018 \\
(0.062)\end{array}$ & $\begin{array}{c}0.001 \\
(0.068)\end{array}$ & $\begin{array}{l}-0.026 \\
(0.061)\end{array}$ \\
\hline December*drinking water on school premises & $\begin{array}{l}-0.002 \\
(0.025)\end{array}$ & $\begin{array}{c}0.005 \\
(0.027)\end{array}$ & $\begin{array}{l}-0.008 \\
(0.028)\end{array}$ \\
\hline December*functional toilet for girls & $\begin{array}{c}0.056 \\
(0.053)\end{array}$ & $\begin{array}{c}0.044 \\
(0.053)\end{array}$ & $\begin{array}{c}0.075 \\
(0.057)\end{array}$ \\
\hline December* school enrollment in July & $\begin{array}{c}0.000 \\
(0.000)\end{array}$ & $\begin{array}{c}0.000 \\
(0.000)\end{array}$ & $\begin{array}{c}0.000 \\
(0.000)\end{array}$ \\
\hline December* school attendance rate in July & $\begin{array}{l}0.464 * * * \\
(0.080)\end{array}$ & $\begin{array}{l}0.418 * * * \\
(0.086)\end{array}$ & $\begin{array}{l}0.505^{* * * *} \\
(0.092)\end{array}$ \\
\hline Constant & $\begin{array}{l}0.814 * * * \\
(0.020)\end{array}$ & $\begin{array}{l}0.815 * * * \\
(0.022)\end{array}$ & $\begin{array}{l}0.813 * * * \\
(0.021)\end{array}$ \\
\hline Observations & 112 & 108 & 108 \\
\hline R-squared & 0.16 & 0.13 & 0.16 \\
\hline
\end{tabular}

Note: Standard errors corrected for clustering on the school reported in parentheses. Missing data for 2 girls only school and 2 boys only school.* Significant at $10 \%, * * 5 \%$ and $* * * 1 \%$ 
Table 3: Impact of School Meal Program on Monthly Attendance Rates in Public Primary Schools by Gender and Grade

\begin{tabular}{|c|c|c|c|c|c|c|c|c|c|c|}
\hline \multirow[t]{2}{*}{ Variables } & \multicolumn{5}{|c|}{ Boys } & \multicolumn{5}{|c|}{ Girls } \\
\hline & Grade 1 & Grade 2 & Grade 3 & Grade 4 & Grade 5 & Grade 1 & Grade 2 & Grade 3 & Grade 4 & Grade 5 \\
\hline $\begin{array}{l}\text { December*Participation in cooked meal } \\
\text { program after July but before December }\end{array}$ & $\begin{array}{c}0.076 \\
(0.059)\end{array}$ & $\begin{array}{l}-0.016 \\
(0.051)\end{array}$ & $\begin{array}{c}0.009 \\
(-0.054)\end{array}$ & $\begin{array}{l}-0.012 \\
(0.054)\end{array}$ & $\begin{array}{l}-0.058 \\
(0.059)\end{array}$ & $\begin{array}{l}0.124 * * \\
(0.056)\end{array}$ & $\begin{array}{l}-0.006 \\
(0.063)\end{array}$ & $\begin{array}{l}-0.014 \\
(0.044)\end{array}$ & $\begin{array}{c}0.003 \\
(0.054)\end{array}$ & $\begin{array}{l}-0.048 \\
(0.062)\end{array}$ \\
\hline Participation in cooked meal program after & & & & & & & & & & \\
\hline July but before December & $\begin{array}{l}-0.123 * * \\
(0.054)\end{array}$ & $\begin{array}{l}-0.035 \\
(0.039)\end{array}$ & $\begin{array}{l}-0.011 \\
(0.048)\end{array}$ & $\begin{array}{l}-0.007 \\
(0.040)\end{array}$ & $\begin{array}{c}0.002 \\
(0.055)\end{array}$ & $\begin{array}{l}-0.137 * * * \\
(0.048)\end{array}$ & $\begin{array}{l}-0.035 \\
(0.049)\end{array}$ & $\begin{array}{l}-0.038 \\
(0.036)\end{array}$ & $\begin{array}{l}-0.017 \\
(0.042)\end{array}$ & $\begin{array}{c}0.009 \\
(0.052)\end{array}$ \\
\hline December & $\begin{array}{l}-0.598 * * * \\
(0.130)\end{array}$ & $\begin{array}{l}-0.442 * * * \\
(0.155)\end{array}$ & $\begin{array}{l}-0.341 * * \\
(0.153)\end{array}$ & $\begin{array}{l}-0.242 * * \\
(0.110)\end{array}$ & $\begin{array}{c}0.062 \\
(0.092)\end{array}$ & $\begin{array}{l}-0.483 * * * \\
(0.172)\end{array}$ & $\begin{array}{l}-0.431 * * * \\
(0.128)\end{array}$ & $\begin{array}{l}-0.166 \\
(0.225)\end{array}$ & $\begin{array}{l}-0.099 \\
(0.163)\end{array}$ & $\begin{array}{l}-0.038 \\
(0.137)\end{array}$ \\
\hline December*pupil-teacher ratio & $\begin{array}{c}0.000 \\
(0.001)\end{array}$ & $\begin{array}{c}0.000 \\
(0.000)\end{array}$ & $\begin{array}{c}0.000 \\
(0.000)\end{array}$ & $\begin{array}{c}0.000 \\
(0.001)\end{array}$ & $\begin{array}{c}0.000 \\
(0.001)\end{array}$ & $\begin{array}{c}0.000 \\
(0.001)\end{array}$ & $\begin{array}{c}0.000 \\
(0.001)\end{array}$ & $\begin{array}{l}-0.001^{*} \\
(0.001)\end{array}$ & $\begin{array}{c}0.000 \\
(0.001)\end{array}$ & $\begin{array}{l}-0.001 \\
(0.001)\end{array}$ \\
\hline December*blackboards per grade & $\begin{array}{l}-0.102 \\
(0.087)\end{array}$ & $\begin{array}{c}0.004 \\
(0.072)\end{array}$ & $\begin{array}{l}0.06 \\
(0.116)\end{array}$ & $\begin{array}{c}0.065 \\
(0.094)\end{array}$ & $\begin{array}{c}0.091 \\
(0.095)\end{array}$ & $\begin{array}{c}0.013 \\
(0.087)\end{array}$ & $\begin{array}{c}0.005 \\
(0.108)\end{array}$ & $\begin{array}{c}0.086 \\
(0.088)\end{array}$ & $\begin{array}{l}-0.086 \\
(0.083)\end{array}$ & $\begin{array}{l}-0.013 \\
(0.072)\end{array}$ \\
\hline $\begin{array}{l}\text { December*drinking water on school } \\
\text { premises }\end{array}$ & $\begin{array}{l}-0.018 \\
(0.038)\end{array}$ & $\begin{array}{c}0.018 \\
(0.030)\end{array}$ & $\begin{array}{l}-0.051 \\
(0.053)\end{array}$ & $\begin{array}{c}0.042 \\
(0.039)\end{array}$ & $\begin{array}{c}0.030 \\
(0.033)\end{array}$ & $\begin{array}{c}0.000 \\
(0.044)\end{array}$ & $\begin{array}{c}0.004 \\
(0.048)\end{array}$ & $\begin{array}{l}-0.009 \\
(0.037)\end{array}$ & $\begin{array}{l}-0.024 \\
(0.037)\end{array}$ & $\begin{array}{c}0.004 \\
(0.032)\end{array}$ \\
\hline December*functional toilet for girls & $\begin{array}{c}0.019 \\
(0.050)\end{array}$ & $\begin{array}{c}0.004 \\
(0.086)\end{array}$ & $\begin{array}{c}0.033 \\
(0.066)\end{array}$ & $\begin{array}{c}0.087 \\
(0.060)\end{array}$ & $\begin{array}{c}0.065 \\
(0.060)\end{array}$ & $\begin{array}{l}0.005 \\
(0.125)\end{array}$ & $\begin{array}{c}0.090^{*} \\
(0.051)\end{array}$ & $\begin{array}{l}0.110 * * \\
(0.045)\end{array}$ & $\begin{array}{r}0.109^{*} \\
(0.054)\end{array}$ & $\begin{array}{c}0.001 \\
(0.076)\end{array}$ \\
\hline December* school enrollment in July & $\begin{array}{c}0.000 \\
(0.000)\end{array}$ & $\begin{array}{c}0.000 \\
(0.000)\end{array}$ & $\begin{array}{c}0.000 \\
(0.000)\end{array}$ & $\begin{array}{c}0.000 \\
(0.001)\end{array}$ & $\begin{array}{c}0.001 \\
(0.001)\end{array}$ & $\begin{array}{c}0.000 \\
(0.001)\end{array}$ & $\begin{array}{c}0.000 \\
(0.001)\end{array}$ & $\begin{array}{c}0.000 \\
(0.000)\end{array}$ & $\begin{array}{c}0.000 \\
(0.000)\end{array}$ & $\begin{array}{c}0.000 \\
(0.001)\end{array}$ \\
\hline December* school attendance rate in July & $\begin{array}{l}0.802 * * * \\
(0.142)\end{array}$ & $\begin{array}{l}0.577 * * * \\
(0.167)\end{array}$ & $\begin{array}{l}0.383 * * \\
(0.166)\end{array}$ & $\begin{array}{l}0.286^{* *} \\
(0.133)\end{array}$ & $\begin{array}{c}0.017 \\
(0.119)\end{array}$ & $\begin{array}{l}0.601 * * * \\
(0.192)\end{array}$ & $\begin{array}{l}0.524 * * * \\
(0.163)\end{array}$ & $\begin{array}{c}0.166 \\
(0.255)\end{array}$ & $\begin{array}{c}0.166 \\
(0.187)\end{array}$ & $\begin{array}{c}0.243 \\
(0.154)\end{array}$ \\
\hline Constant & $\begin{array}{l}0.786 \text { *** } \\
(0.044)\end{array}$ & $\begin{array}{l}0.862 * * * \\
(0.029)\end{array}$ & $\begin{array}{l}0.822 * * * \\
(0.032)\end{array}$ & $\begin{array}{l}0.816^{* * * *} \\
(0.031)\end{array}$ & $\begin{array}{l}0.796 * * * \\
(0.045)\end{array}$ & $\begin{array}{l}0.785^{* * * *} \\
(0.036)\end{array}$ & $\begin{array}{l}0.818^{* * *} \\
(0.040)\end{array}$ & $\begin{array}{l}0.849 * * * \\
(0.024)\end{array}$ & $\begin{array}{l}0.834 * * * \\
(0.030)\end{array}$ & $\begin{array}{l}0.790^{* * *} \\
(0.040)\end{array}$ \\
\hline Observations & 108 & 108 & 108 & 108 & 108 & 108 & 108 & 108 & 108 & 106 \\
\hline R-squared & 0.22 & 0.17 & 0.05 & 0.07 & 0.08 & 0.2 & 0.09 & 0.07 & 0.03 & 0.1 \\
\hline
\end{tabular}

Note: Standard errors corrected for clustering on the school reported in parentheses. Missing data for no girl enrollment in grade 5.

$*$ Significant at $10 \%, * * 5 \%$ and $* * * 1 \%$ 
Table 4: Impact of School Meal Program on Enrollment Levels in Public Primary Schools

\begin{tabular}{lccc}
\hline Variables & All & Boys & Girls \\
\hline December*Participation in cooked meal program after July but before December & -10.026 & -4.122 & -5.904 \\
& $(17.395)$ & $(8.382)$ & $(10.111)$ \\
Participation in cooked meal program after July but before December & 10.302 & 3.4 & 6.902 \\
& $(17.597)$ & $(9.644)$ & $(9.746)$ \\
December & $-93.263^{* * *}$ & -33.873 & $-59.39^{* * *}$ \\
& $(14.875)$ & $(21.629)$ & $(19.251)$ \\
December*pupil-teacher ratio & 0.003 & 0.098 & -0.095 \\
& $(0.026)$ & $(0.107)$ & $(0.094)$ \\
December*blackboards per grade & 3.356 & 5.167 & -1.811 \\
& $(2.884)$ & $(12.995)$ & $(12.818)$ \\
December*drinking water on school premises & 0.232 & -3.274 & 3.506 \\
& $(1.316)$ & $(4.684)$ & $(4.264)$ \\
December*functional toilet for girls & 2.072 & 4.190 & -2.119 \\
& $(3.527)$ & $(4.865)$ & $(3.464)$ \\
December* school enrollment in July & $0.951 * * *$ & $0.375^{* * *}$ & $0.576^{* * *}$ \\
& $(0.028)$ & $(0.101)$ & $(0.091)$ \\
December* school attendance rate in July & -0.058 & -11.691 & 11.632 \\
& $(4.513)$ & $(23.53)$ & $(21.258)$ \\
Constant & $94.647 * * *$ & $49.882^{* * *}$ & $44.765^{* * *}$ \\
& $(15.052)$ & $(8.106)$ & $(7.178)$ \\
\hline Observations & 112 & 112 & 112 \\
R-squared & 0.48 & 0.31 & 0.36 \\
\hline
\end{tabular}

Note: Standard errors corrected for clustering on the school reported in parentheses.

$*$ Significant at $10 \%, * * 5 \%$ and $* * * 1 \%$ 
Table 5: Impact of School Meal Program on Enrollment Levels in Public Primary Schools by Gender and Grade

\begin{tabular}{|c|c|c|c|c|c|c|c|c|c|c|}
\hline \multirow[t]{2}{*}{ Variables } & \multicolumn{5}{|c|}{ Boys } & \multicolumn{5}{|c|}{ Girls } \\
\hline & Grade 1 & Grade 2 & Grade 3 & Grade 4 & Grade 5 & Grade 1 & Grade 2 & Grade 3 & Grade 4 & Grade 5 \\
\hline $\begin{array}{l}\text { December*Participation in cooked meal } \\
\text { program after July but before December }\end{array}$ & $\begin{array}{l}-0.777 \\
(2.102)\end{array}$ & $\begin{array}{c}0.086 \\
(1.599)\end{array}$ & $\begin{array}{l}-2.104 \\
(2.005)\end{array}$ & $\begin{array}{l}-0.679 \\
(1.813)\end{array}$ & $\begin{array}{l}-0.649 \\
(1.621)\end{array}$ & $\begin{array}{l}-0.994 \\
(2.008)\end{array}$ & $\begin{array}{l}-1.181 \\
(2.150)\end{array}$ & $\begin{array}{l}-1.230 \\
(2.195)\end{array}$ & $\begin{array}{l}-1.521 \\
(1.887)\end{array}$ & $\begin{array}{l}-0.979 \\
(2.436)\end{array}$ \\
\hline $\begin{array}{l}\text { Participation in cooked meal program } \\
\text { after July but before December }\end{array}$ & $\begin{array}{c}0.350 \\
(2.391)\end{array}$ & $\begin{array}{c}1.100 \\
(1.895)\end{array}$ & $\begin{array}{c}1.335 \\
(2.132)\end{array}$ & $\begin{array}{c}0.428 \\
(2.274)\end{array}$ & $\begin{array}{c}0.187 \\
(2.051)\end{array}$ & $\begin{array}{l}-0.680 \\
(2.323)\end{array}$ & $\begin{array}{c}1.189 \\
(2.240)\end{array}$ & $\begin{array}{l}1.519 \\
(2.320)\end{array}$ & $\begin{array}{l}3.275^{*} \\
(1.836)\end{array}$ & $\begin{array}{l}1.600 \\
(2.404)\end{array}$ \\
\hline December & $\begin{array}{l}-3.430 \\
(7.703)\end{array}$ & $\begin{array}{l}-11.164 * * * \\
(3.801)\end{array}$ & $\begin{array}{l}-7.665^{*} \\
(3.874)\end{array}$ & $\begin{array}{l}-7.702 \\
(5.341)\end{array}$ & $\begin{array}{l}-3.912 \\
(5.009)\end{array}$ & $\begin{array}{l}-3.406 \\
(6.490)\end{array}$ & $\begin{array}{l}-15.724 * * * \\
(4.174)\end{array}$ & $\begin{array}{c}-14.597 * * * \\
(5.440)\end{array}$ & $\begin{array}{c}-11.691 * * * \\
(3.287)\end{array}$ & $\begin{array}{c}-13.971 * * * \\
(4.157)\end{array}$ \\
\hline December*pupil-teacher ratio & $\begin{array}{l}0.061 * \\
(0.032)\end{array}$ & $\begin{array}{l}0.048 * * \\
(0.022)\end{array}$ & $\begin{array}{c}0.013 \\
(0.024)\end{array}$ & $\begin{array}{l}-0.026 \\
(0.030)\end{array}$ & $\begin{array}{c}0.002 \\
(0.022)\end{array}$ & $\begin{array}{c}0.012 \\
(0.026)\end{array}$ & $\begin{array}{l}-0.006 \\
(0.023)\end{array}$ & $\begin{array}{c}0.004 \\
(0.029)\end{array}$ & $\begin{array}{l}-0.042 * \\
(0.023)\end{array}$ & $\begin{array}{l}-0.062 * \\
(0.031)\end{array}$ \\
\hline December*blackboards per grade & $\begin{array}{c}2.408 \\
(4.567)\end{array}$ & $\begin{array}{l}-0.490 \\
(2.955)\end{array}$ & $\begin{array}{c}6.241 * \\
(3.305)\end{array}$ & $\begin{array}{l}-2.614 \\
(2.989)\end{array}$ & $\begin{array}{l}-0.378 \\
(3.535)\end{array}$ & $\begin{array}{c}4.184 \\
(3.568)\end{array}$ & $\begin{array}{l}-1.573 \\
(3.110)\end{array}$ & $\begin{array}{c}1.203 \\
(3.679)\end{array}$ & $\begin{array}{l}-3.962 \\
(2.720)\end{array}$ & $\begin{array}{l}-1.663 \\
(3.627)\end{array}$ \\
\hline $\begin{array}{l}\text { December*drinking water on school } \\
\text { premises }\end{array}$ & $\begin{array}{l}-0.009 \\
(1.782)\end{array}$ & $\begin{array}{l}-0.422 \\
(1.270)\end{array}$ & $\begin{array}{l}3.212^{* *} \\
(1.254)\end{array}$ & $\begin{array}{l}-1.034 \\
(1.338)\end{array}$ & $\begin{array}{c}1.403 \\
(1.201)\end{array}$ & $\begin{array}{c}0.252 \\
(1.242)\end{array}$ & $\begin{array}{c}1.567 \\
(1.226)\end{array}$ & $\begin{array}{c}0.724 \\
(1.213)\end{array}$ & $\begin{array}{c}0.442 \\
(1.243)\end{array}$ & $\begin{array}{c}0.520 \\
(1.433)\end{array}$ \\
\hline December*functional toilet for girls & $\begin{array}{l}-1.775 \\
(1.210)\end{array}$ & $\begin{array}{l}2.269 \\
(1.891)\end{array}$ & $\begin{array}{c}4.531 \\
(3.680)\end{array}$ & $\begin{array}{l}-1.525 \\
(2.785)\end{array}$ & $\begin{array}{c}0.690 \\
(0.898)\end{array}$ & $\begin{array}{l}-4.344 * * * \\
(1.202)\end{array}$ & $\begin{array}{c}2.636 \\
(1.820)\end{array}$ & $\begin{array}{l}1.746 \\
(1.601)\end{array}$ & $\begin{array}{c}0.073 \\
(2.021)\end{array}$ & $\begin{array}{l}-2.230 \\
(1.495)\end{array}$ \\
\hline December* July school enrollment & $\begin{array}{l}0.068 * * \\
(0.028)\end{array}$ & $\begin{array}{l}0.060 * * * \\
(0.019)\end{array}$ & $\begin{array}{l}0.072 * * * \\
(0.021)\end{array}$ & $\begin{array}{l}0.108 * * * \\
(0.026)\end{array}$ & $\begin{array}{l}0.066^{* * * *} \\
(0.023)\end{array}$ & $\begin{array}{l}0.091 * * * \\
(0.019)\end{array}$ & $\begin{array}{l}0.118 * * * \\
(0.021)\end{array}$ & $\begin{array}{l}0.106 * * * \\
(0.027)\end{array}$ & $\begin{array}{l}0.131 * * * \\
(0.016)\end{array}$ & $\begin{array}{l}0.130 * * * \\
(0.028)\end{array}$ \\
\hline December* July school attendance & $\begin{array}{l}-8.763 \\
(9.077)\end{array}$ & $\begin{array}{c}3.306 \\
(4.250)\end{array}$ & $\begin{array}{l}-2.214 \\
(3.401)\end{array}$ & $\begin{array}{c}0.467 \\
(5.387)\end{array}$ & $\begin{array}{l}-4.486 \\
(5.644)\end{array}$ & $\begin{array}{l}-9.321 \\
(7.456)\end{array}$ & $\begin{array}{c}6.116 \\
(4.586)\end{array}$ & $\begin{array}{c}3.935 \\
(5.834)\end{array}$ & $\begin{array}{c}4.719 \\
(3.876)\end{array}$ & $\begin{array}{c}6.184 \\
(3.892)\end{array}$ \\
\hline Constant & $\begin{array}{l}11.471 * * * \\
(1.968)\end{array}$ & $\begin{array}{l}8.824 * * * \\
(1.545)\end{array}$ & $\begin{array}{l}9.588 * * * \\
(1.636)\end{array}$ & $\begin{array}{l}10.059 * * * \\
(1.836)\end{array}$ & $\begin{array}{l}9.941 * * * \\
(1.748)\end{array}$ & $\begin{array}{l}11.706 * * * \\
(2.015)\end{array}$ & $\begin{array}{l}8.529 * * * \\
(1.747)\end{array}$ & $\begin{array}{l}9.353 * * * \\
(1.884)\end{array}$ & $\begin{array}{l}7.059 * * * \\
(1.123)\end{array}$ & $\begin{array}{l}8.118 * * * \\
(1.465)\end{array}$ \\
\hline Observations & 112 & 112 & 112 & 112 & 112 & 112 & 112 & 112 & 112 & 112 \\
\hline R-squared & 0.26 & 0.27 & 0.3 & 0.24 & 0.19 & 0.35 & 0.32 & 0.32 & 0.34 & 0.22 \\
\hline
\end{tabular}

Note: Standard errors corrected for clustering on the school reported in parentheses. * Significant at 10\%, ** 5\% and ***1\% 
Table 6: Annual Household Expenditure on Public Schooling of an Individual Child (Rs. per annum)

\begin{tabular}{llllll}
\hline Expenditure Category & $\begin{array}{l}\text { Grade 1 } \\
(\mathbf{N = 2 1 4})\end{array}$ & $\begin{array}{l}\text { Grade 2 } \\
(\mathbf{N = 1 5 5})\end{array}$ & $\begin{array}{l}\text { Grade 3 } \\
(\mathbf{N}=193)\end{array}$ & $\begin{array}{l}\text { Grade 4 } \\
(\mathbf{N}=175)\end{array}$ & $\begin{array}{l}\text { Grade 5 } \\
(\mathbf{N}=168)\end{array}$ \\
\hline Tuition and other fees & 23.84 & 25.58 & 33.27 & 31.89 & 39.80 \\
& $(24.006)$ & $(20.399)$ & $(27.275)$ & $(22.984)$ & $(25.598)$ \\
Text Books & 7.78 & 10.68 & 17.00 & 23.79 & 29.83 \\
& $(13.292)$ & $(17.396)$ & $(24.202)$ & $(35.675)$ & $(36.598)$ \\
Stationary & 26.23 & 36.75 & 48.37 & 55.34 & 62.35 \\
& $(16.945)$ & $(28.351)$ & $(29.087)$ & $(34.573)$ & $(32.778)$ \\
Uniform & 60.47 & 75.06 & 83.6 & 93.71 & 112.02 \\
& $(69.431)$ & $(67.732)$ & $(74.494)$ & $(78.091)$ & $(82.053)$ \\
$\begin{array}{l}\text { Other expenses } \\
\text { (including }\end{array}$ & 0.00 & 0.06 & 0.05 & 0.23 & 0.74 \\
transportation) & $(0.000)$ & $(0.803)$ & $(0.720)$ & $(1.763)$ & $(7.827)$ \\
\hline Total Annual Cost & $\mathbf{1 1 8 . 3 2}$ & $\mathbf{1 4 8 . 1 3}$ & $\mathbf{1 8 2 . 2 9}$ & $\mathbf{2 0 4 . 9 6}$ & $\mathbf{2 4 4 . 7 4}$ \\
& $(85.810)$ & $(88.860)$ & $(96.944)$ & $(111.086)$ & $(113.822)$ \\
\hline $\begin{array}{l}\text { Cash value of cooked } \\
\text { meals as \% of annual }\end{array}$ & 161.43 & 129.41 & 104.78 & 93.19 & 78.04 \\
schooling cost & & & & & \\
\hline $\begin{array}{l}\text { Total daily calorie } \\
\text { intake }(\boldsymbol{k} \text { cal) }\end{array}$ & 1138.02 & 1326.71 & 1347.16 & 1389.658 & 1512.06 \\
& $(350.348)$ & $(465.030)$ & $(434.856)$ & $(414.164)$ & $(467.713)$ \\
& & & & &
\end{tabular}

Note: Standard deviations reported in parentheses.

${ }^{+}$Cash value of cooked meal includes the market value of wheat (Rs. 0.70 per 100 grams) and the cost of ingredients (Rs. 0.255 per student per school day). There are approximately 200 school days each academic year. With each student receiving 100 grams of wheat per school day the annual cash value of the program is Rs. 191 per student across all grades in 2003-04 prices.

The tuition costs reported here are based on the response of households while in Table 1 it is based on school level data.

Source: The data are based on a sample survey conducted in January-February, 2004 of 905 children enrolled in a public primary school and residing within 615 households in the 41 villages in the survey area. 